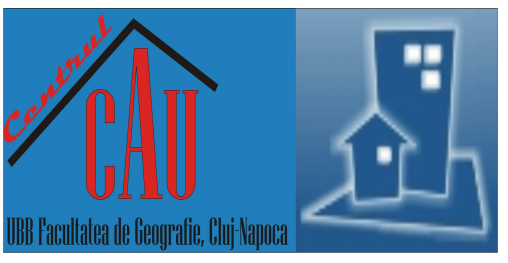

\title{
Alternative Food Networks in Romania - Effective Instrument for Rural Development?
}

\author{
Kinga Xénia HAVADI-NAGY ${ }^{*}$ \\ * Corresponding author \\ 1 Babeș-Bolyai University, Faculty of Geography, Department of Regional Geography and Territorial Planning, Cluj-Napoca, ROMANIA \\ $\triangle$ kinga.havadi@ubbcluj.ro (D) https://orcid.org/oooo-0oo2-9182-3824 \\ DOI: 10.24193/JSSPSI.2021.8.03 \\ https://doi.org/10.24193/JSSPSI.2021.8.03
}

Ke y w o r d s: conscious consumption, sustainable food production and distribution, Romania

\begin{abstract}
A B S T RA C T
Recent public policies in the European Union foster a new multifunctional agricultural model, which, besides the food production function of farms, address the ecological, cultural, and social services they deliver, so that agriculture may contribute to an overall rural development. These benefits are produced mainly by small-scale farmers, which are less intensive and focusing on diversification. Alternative food networks (AFN) are the result of an amalgam of socio-cultural and economic phenomena, one main aim of these initiatives being the support of smallholders. This study reflects upon the chances and challenges of AFNs in the Romanian context, based on the existing initiatives emerging under the current socio-political and economic circumstances. The objective of the survey is to reveal the growth possibilities of AFNs and their potential contribution to the appreciation of small-scale agriculture and a sustainable, liveable rural area. The survey relies on data from previous research, the up-to-date websites and social network platforms of the investigated initiatives, informal discussions with AFN stakeholders, and the observations conducted by the author as a consumer of AFNs based in Cluj-Napoca. For the applied policies and policy recommendations, we consulted the main national policy documents and rural development strategies. We can conclude that Romania holds significant resources for the implementation of alternative food networks due to numerous favourable circumstances. However, to become an efficient tool of rural development, we see a need of improvement in accessibility, institutional and policy support, as well as in the education of producers and consumers in the spirit of sustainable consumption.
\end{abstract}

\section{INTRODUCTION}

The modernization of agriculture over the past decades improved the access to sufficient, safe, and affordable food in Europe (De Olde and Valentinov, 2019), however, the conventional food network (CFN), the "productionist, industrial, modernist, agriproduction systems, feeding into long, opaque, increasingly globalised food processing/retailing/ consumption chains" (Jones et al., 2010, p. 96) have caused a series of socio-economic and environmental prejudices which turned into issues of broad societal and political debate (Harris, 2010; De Olde and Valentinov, 2019).
Following the aggravating discontent with conventional food systems, the new demands of conscious consumers, with a growing preoccupation for the place of origin of food, completed by increasing interest in food authenticity and diversity (Robinson, 2013), efforts to create alternatives and mitigate the negative consequences of delocalized industrial agriculture (Watts, Ilbery and Maye, 2005) have sought to reconnect food systems with places and people. These alternatives are endeavours to generate viable solutions that are significantly different, diverse, multifaceted, and thoroughly adjusted to the given context (McMichael, 2010, in Smeds, 2015), mostly grassroots movements established on local culture, farm 
household potential and agri-ecology (Robinson, 2013), developed by consumers and producers.

The alternative food networks (AFN) are the result of an amalgam of socio-cultural and economic phenomena, and, as such, emerged within "processes of global economic restructuring, rural decline and redevelopment, environmental concerns and progressive political ideals" (Harris, 2010, p. 355). The triggering force of this upheaval is the 'new consumer', whose priorities are ethical, environmental, and health concerns, neglecting the appearance, purchase cost, packaging, and convenience of food shopping and preparation (Robinson, 2013; Smutna, 2018).

These new attempts are globally spreading, and they are reflected also in the revaluation of agriculture in Europe, where the goal "is no longer simply to maximize productivity and profitability but to optimize across a far more complex range of production, rural development, environmental, social and food consumption outcomes" (Bos et al., 2013, in De Olde and Valentinov, 2019, p. 415). This new approach to agriculture is reflected in the topics and focus of various EU policies. As a member state of the EU, Romania adopted these policies and started to implement them.

This study aims to reflect upon the chances and challenges of AFNs in the Romanian context, based on the existing alternative food networks emerged under the current socio-political and economic circumstances. The objective of this survey is to reveal the growth possibilities of AFNs and their potential contribution to the appreciation of small-scale agriculture and a sustainable rural area.

\section{THEORY AND METHODOLOGY}

\subsection{Concepts and definitions}

The rich and various international literature investigating AFN and short food supply chain (SFSC) related phenomena, participating stakeholders, types, advantages, and disadvantages, as well as the cost and benefits of alternative food networks reflects the strong interest towards this topic among academia, practitioners, policymakers, and decision takers.

Dansero and Puttilli (2014) differentiate among two main phases of the history of literature on AFNs. In the first phase, starting in the mid-199os, AFNs were regarded as "a radical, antagonistic alternative to a dominant system centred on industrial agriculture and organised on large-scale distribution" (Dansero and Puttilli, 2014, p. 628). The literature from this period considered the standardised conventional agri-industrial production model as being "socially unjust, environmentally unsustainable and risky from the point of view of health and food consumption" (Dansero and Puttilli, 2014, p. 628). In this view, AFNs emerged "as a niche which embraced numerous very tangible and ethical experiences defined as local, correct, profitable, sustainable and qualitative" (Dansero and Puttilli, 2014, p. 628).

From 2000 onwards, there is a change of discourse in the literature on AFNs towards a more critical stance, attempting to analyse and find answers to unsolved social, environmental, and economic issues, by applying different disciplinary approaches and comprising a variety of case studies (Dansero and Puttilli, 2014).

As a result of a comprehensive research, the dualistic approach of the food market, split into strictly delimited long industrial food chain and short alternative food chains, successively allowed the view in which AFNs are regarded and assessed as one potential strategy to organise the production, distribution, and consumption of food, with possible competitive coexistence and every so often overlapping with elements of the conventional food chains (Dansero and Puttilli, 2014).

Alternative food networks are the result of political, cultural, and historical processes (Jarosz, 2017) resulting in a multitude of variations, but at the same time comprising some common features. Even though several definitions of alternative food networks and short food supply chains emphasise the reduction of intermediaries and the physical distance between producers and consumers (Mastroiandi et al., 2015; Barbera and Dagnesa, 2016; Berti and Mulligan, 2016; Jarosz, 2017), more relevant aspects in the differentiation of the CFNs are:

- their capacity to re-socialize and to respatialize food production, distribution and consumption, assuring credibility, trustworthiness, and transparency of food production and provenance (Sage, 2003b; Goodman and Goodman, 2009; Berti and Mulligen, 2016);

- the fact that the consumer obtains the product embedded with information (about the values of the producers, production procedures) (Marsden, Banks and Bristow, 2000; Harris, 2010), creates social relations, reciprocity and trust that modify and enhance economic exchange (Hinrichs, 2000, in Bilewicz and Śpiewak, 2015);

- their facilitation of valuable connections between producers and consumers, based on democratic power relations, trust and equity (Marsden, Banks and Bristow, 2000; Harris, 2010; Barbera and Dagnesa, 2016; Berti and Mulligen, 2016; Smutna, 2018), enabling them to have an active role in the food system (Galli and Brunori, 2013);

- the creation of new forms of political associations and governance (Whatmore et al., 2003, in Sage, 2003b; Santini and Gomez y Paloma, 2013; Berti and Mulligen, 2016) of actors sharing the same goals and values; 


\section{Alternative Food Networks in Romania - Effective Instrument for Rural Development? Journal of Settlements and Spatial Planning, Special Issue, no. 8 (2021) 15-27 Territorial Identities and Sustainable Development. Challenges and Solutions}

- their enabling health, economic, environmental, and social gains and advantages to the communities in the areas they operate (Jarosz, 2008; Santini and Gomez y Paloma, 2013; Berti and Mulligen, 2016);

- the involvement of rather smallholders and organic or holistic farming methods (Jarosz, 2008), which would enhance environmental sustainability (Wubben, Fondse and Pascucci, 2013).

"Short food supply chains", "alternative (agri-) food networks", "local food networks" or even "valuebased food supply chains" or "alternative food economies" are a series of concepts that encompass a wide range of food production and distribution activities which disapprove the defining features of conventional agriculture and supply chains, such as excessive productivity, industrial work flow and standards, prioritizing instead features, such as quality, authenticity and the "naturality" of agri-food production, health issues, environment and fair trade (Robinson, 2013; Mastronardi et al., 2015). These closely related collective nouns merge a great spectrum of mostly grass-roots, consumer-driven (Bilewicz and Śpiewak, 2015) food networks, ranging from organics and fair trade to regional and artisanal products that constitute a swiftly evolving and expanding food market in Europe (Whatmore, Stassart and Renting, 2003).

In this paper, we prefer to adopt the denomination of short food supply chain which focuses on the essence of the relationship between the producer and consumer, rather than arguing about the definition of "local", and the concept of alternative (agri-)food networks, which reflect the poly-valency and multidirectionality of the movements (Sage, 2003b) and the new interactions among the involved actors.

This wide range of SFSC models and schemes justifies the ambitions of researchers to systemize alternative food networks. Attempts to grasp the diversity of SFSCs focus on aspects like: specific quality definitions and conventions (Renting, Marsden and Banks, 2003), organisation forms and number of intermediaries (Galli and Brunori, 2013), organisation and initiators (Galli and Brunori, 2013), level of compromise adopted either by producers or consumers (Mundubat, 2012, in Galli and Brunori, 2013), level of involvement of the consumers in the production, combined with the purpose of the payments (Wellner, 2018), organisation form of consumers and producers, length of supply chain and the level of commitment (Chiffoleau, Millet-Amrani and Canard, 2016). A widespread classification referenced by numerous researchers (cf. Sage, 2003b; Galli and Brunori, 2013) is the one structured by the research group involved in the "Impact" project (Renting, Marsden and Banks, 2003), which defines three main types of short food chains according to the number of intermediaries, physical distance and organisational forms: a). Face-to-face SFSCs with immediate personal trade interaction between consumer and producer/processor, which also assures authenticity and trust (CSA, on-farm sales, off-farms sales);

b). Proximate SFSCs often include intermediary actors (warranty for the product authenticity) in the supply chain and are essentially marketing goods produced within a certain region of production. The retailer provides information to the consumers about the "local" nature of the product (e.g. food hubs, delivery schemes);

c). In the case of spatially extended SFSCs, consumers do not purchase in the production region and may have no direct connection to it. However, knowledge and details about the origin of the product and the producers is conveyed (e.g. on-line sales, certification labels, hospitality industry (HoReCa), speciality retailers, and fair trade).

In their comprehensive research on short food supply chains in the EU, Santini and Gomez y Paloma (2013) point out a wide range of SFSCs, whereby they differentiate between two main groups. The first includes the "traditional" SFSCs, which are set in rural environment, usually operated on and by family farms and applying traditional and artisan production methods. The "neotraditional" SFSCs are more complex collaborative networks, mostly off-farm, established in urban and peri-urban areas, with a great emphasis on social, ethical, and environmental principles. Both models can be ingenious and dynamic, and individual cases combine even the features of both groups in a "hybrid" way (Santini and Gomez y Paloma, 2013).

Urbanization and socio-economic transformation of the rural space are decisive to the development of AFNs (Jarosz, 2008). That is why SFSCs are often mentioned in the context of rural (Marsden, Banks and Bristow, 2000; Galli and Brunori, 2013; Petropoulou, 2016) and regional (Jarosz, 2008; Mundler and Laughrea, 2016) development strategies.

However, SFSCs are still a niche phenomenon, and the current intensity and presence of the sector is insufficient to induce beneficial socio-economic and environmental impacts on a large scale (Aggestam, Fleiß and Posch, 2017). Three elements seem to be required to make SFSCs a real alternative for mass food production and conventional distribution and consumption (Barbera and Dagnesa, 2016):

a). Accessibility (spatial distribution of AFNs, price of agri-food goods, avoidance of possible social exclusion due to excess of localism or the focus on higher-income consumers).

b). Quality: The AFNs emphasise rather on the "soft quality" aspects, focusing on the features of the involved actors and the local context, including the role of tradition, trust, relations, connections, consideration for the environment, community values, and farmers' commitment (Barbera and Dagnesa, 2016), on food 
properties such as taste, look, socio-cultural environment of its origin, and the social dimension of embeddedness, reliability, societal benefits of goods (Sage, 2003b; Goodman and Goodman, 2009; Bilewicz and Śpiewak, 2015), and on gastronomic virtues (Sage, 2003b).

c). Sustainability, the key characteristic of AFNs in relation to CFNs, in effect, their very raison d'etre (Jones et al., 2010). It is recommended to regard the limitations of the AFNs, the costs, and benefits that occur both on the demand and the supply side. Assessing all three dimensions of the sustainability of the AFNs is required to obtain a thorough and objective listing of the costs and benefits that alternative food supply strategies present (Jarosz, 2008; Jones et al., 2010; Demartini, Gaviglio and Pirani, 2017).

Governmental policy and decision makers, as well as the industry and civil society organisations increasingly direct their focus towards the SFSCs, given that, with the appropriate endorsement, they can turn into relevant policy tools as trigger force for broader revision of attitudes and practices around food (Galli and Brunori, 2013). Examples of policy areas in which SFSCs can be a useful tool are: (1) sustainable development of rural and urban areas; (2) integrated food production and distribution strategies; (3) public procurement and entrepreneurship; (4) food democracy: SFSCs can increase food supply resilience and act as a trigger force for changes and methods to improve overall sustainability; (5) environmental policy (Seyfang, 2006; Galli and Brunori, 2013).

In the European Union, public policies addressing agriculture seem to be shifting toward a new perception of agricultural output and food production (Ilbery and Maye, 2005). Public policies of the last programming periods support a new multifunctional agricultural model, which, besides the food production function of farms, addresses the ecological, cultural, and social services it delivers. (Mastronardi et al., 2015), so that agriculture may contribute to an overall rural development.

The emphasis on alternative food networks in the European context is reflected by the numerous interdisciplinary research supported by the EU. "Foodlinks" is the result of a collective work of practitioners, policy makers and scientists aiming to illustrate the variety and multitude of SFSCs in Europe and their role in sustainable rural development (Galli and Brunori, 2013). The research entitled "Short Food Supply Chains and Local Food Systems - a state of play of their socio-economic characteristics" investigates the socio-economic features of these endeavours (Santini and Gomez y Paloma, 2013). "Suppliers" (2003-2005) presented case studies of supply chains in various EU member states (Ilbery and Maye, 2005). "Sus-chain" (2003-2005) provided valuable case studies on regional marketing in several EU countries (De Roep and Wiskerke, 2006). "Cofami" conducted a complex comparative analysis on the chances and challenges of developing collective marketing initiatives (Knickel et al., 2008, in Santini and Gomez y Paloma, 2013), whereas "Faanweb" (2008-2010) approached the topic of AFNs from a stakeholder perspective (Karner et al., 2010, in Santini and Gomez y Paloma, 2013).

Regarding Romania, we can identify various types of AFNs unfolding lately, yet most attention has been received by ASAT-partnerships (Asociația pentru Susținerea Agriculturii Țărănești), a community supported agriculture (CSA) scheme, focussing on the driving forces behind theCSA project (Bîrhală and Möllers, 2014), and the practices which might contribute to a bottom-up rural development (Möllers and Bîrhală, 2014). A comprehensive analysis of a food hub pilot project and the viability of this alternative food network in the Romanian context delivers HavadiNagy (2021). Haşdeu (2014) exemplifies existing AFNs in Romania as best practices in the promotion of local heritage and Tanasă (2014) explores the benefits of SFSCs for the development of rural tourism.

A study with a focus on decisive factors in the strategy of economic and social revival of rural areas and the role of local territorial identity in securing public participation is the one of Ilovan and peers (2016). AFNs, their market potential and patterns, are mentioned in the regional study on contemporary agriculture in Romania by Kovács (2003). Smeds (2015) explores the potential of localised and socially embedded food systems in a dynamic and thriving urban centre like Cluj-Napoca, by analysing two different SFSCs.

Examining the scarce literature on AFNs in the Romanian context, we can assert that it is an emerging topic in academia, as it is also an arising phenomenon in practice, however, currently at an incipient stage, with a rather niche value of initiatives. The current study contributes to the literature on AFNs in Romania by reflecting upon the costs and benefits of the SFSCs, their chances to unfold and to support the revival of peasant agriculture as a tool of the new multifunctional agricultural model adopted in the EU.

\subsection{Research methodology}

We decided to depict a series of AFNs functioning in Romania to illustrate their mechanisms, costs and benefits for the involved stakeholders, chances and challenges of growth, and their effectiveness to enhance the socio-economic status of the regions. For this we gathered data from various sources. Valuable data regarding involved stakeholders and products, as well as details concerning communication and logistics, deliver the up-to-date websites and social network platforms of the investigated initiatives: ASAT (Association for the Support of Peasant Agriculture), Bejön a Vidék (The 


\section{Alternative Food Networks in Romania - Effective Instrument for Rural Development? Journal of Settlements and Spatial Planning, Special Issue, no. 8 (2021) 15-27 \\ Territorial Identities and Sustainable Development. Challenges and Solutions}

village comes to the city), Cutia Țăranului (The peasant's box), RAF (Romanian-American Foundation) pilot project with five food hubs, and Székely Gyümölcs (Sekler Fruits).

As a consumer in AFNs based in Cluj-Napoca, the author interacted with producers and the initiators of some surveyed networks (Bejön a vidék and Nod Verde food hub). During these interactions, we conducted observations and informal discussions with AFN stakeholders, with respect to motivations, costs, and benefits of participating in alternative food networks. We assessed the performance of the SFSCs regarding the three demands (accessibility, quality, and sustainability) required to make $\mathrm{AFNs}$ a viable alternative to CFNs.

For the applied policies and policy recommendations, we consulted important national policy documents and rural development strategies authored by the Ministry for Agriculture and Rural Development, namely: "National Rural Development Plan for 2014-2020" (MADR, 2020a); the "Evaluation study V - Small farms and the development of associate forms", in the frame of "The on - going evaluation of NRDP 2014 - 2020 during 2017 - 2020" (MADR, 2019) and "The on-going evaluation of the NRDP 2015-2020 in the time period 2017-2020, Evaluation study II RAI 2019” (MADR, 2020b).

\section{RESULTS AND DISCUSSION}

\subsection{Romania's small farming sector and cooperation willingness}

Following the regime change in 1989, Romania experienced major political, economic, and social transformations. The agriculture suffered mainly from the impact of the deficient (Ancuţa, Ianăş and Muţulescu, 2013), chaotic and painful (Kovács, 2003) structural reorganization of land ownership in the 1990s, which generated a high degree of land fragmentation (Kovács, 2003). The agriculture production of today features a dualistic farm structure (Salasan and Fritzsch, 2009; Möllers and Bîrhală, 2014; Smeds, 2015; Möllers et al., 2018), meaning that about half of the land is owned by a small group of agri-food enterprises and the other half is cultivated by almost four million smallholders.

The last agricultural census conducted in 2010 revealed that small farms operating under 5 hectares represented $93.1 \%$ of total farms but only $29.7 \%$ of the agricultural area, while a small number of large farms with over 50 ha operate the largest part of the arable land (52\%) (MADR, 2019). 99.2\% of the farms have no legal form (MADR, 2020a).

Despite its considerable potential, Romania's agriculture confronts numerous challenges including underused land potential and fragmented agricultural properties, low labour productivity and qualified workforce outmigration, as well as lack of storage and processing units, etc. (Tanasă, Brumă and Doboş, 2015). Further on, Romania has the highest level of employment in agriculture (Möllers et al., 2018), but with a very low level of trained farm labour force and a small number of farm managers with formal agricultural training (Salasan and Fritzsch, 2009). A high share of farm holders are 55 years of age or older. Only $\mathbf{1 7 . 2 \%}$ of the utilised agricultural area (UAA) is managed by farmers of 44 years old or younger (Salasan and Fritzsch, 2009).

Most of the agricultural work is executed by family labour and the agriculture is dominated by subsistence and semi-subsistence farm households, with a low level of productivity (Möllers et al., 2018; Ancuţa, Ianăş and Muţulescu, 2013), and which are not considered drivers of economic development (Salasan and Fritzsch, 2009). Hence, it is obvious that this high number of small-scale farms is regarded as partially culpable for prevalent rural poverty and poor commercialisation.

Smallholder farms face multiple and various constraints (e.g. high transaction costs, inability to meet certain standards), impeding them to open up for commercialisation and to access the market. Although cooperation might be beneficial for these small-scale private farms to mitigate the impediments, it has been said that post-communist Romanian farmers are reluctant to form or join cooperatives, argued by the fact that "the majority of rural households reject cooperation (...) owing to the lack of tradition and spirit of cooperation in certain regions as well as the negative experience of formal cooperation during the time of socialism and transition" (Bálint and Wobst, 2006, in Möllers et al., 2018, 57). However, there is little evidence in the literature to sustain this affirmation.

Worth mentioning is the survey of Möllers et al. (2018), who investigated the factors which determine the formation of the Romanian vegetable cultivators' intention to engage in marketing cooperatives in producer groups (PG) and concluded that the simplified formula, which states that the communist experience extinguished the willingness of farmers to cooperate does not stand. There are multiple ways of cooperation: individuals may work together in informal groups within families, friends, or neighbourhoods, or formally, in the frame of producer groups, associations, or agricultural service cooperatives declared as legal entities to conduct economic operations (Möllers et al., 2018).

Formal registration is decisive to take part in economic life. The Law on Agricultural Cooperatives from 1995 facilitated the formal cooperation among Romanian farmers from early on, but with moderate 
success: although 691 agricultural cooperatives were registered by 2013, merely 162 were economically active (Möllers et al., 2018). The European Union works at improving farmers' presence in the agri-food sector, by incentivising producer organisations (POs) and producer groups. After the accession to the EU, Romania implemented this approach, known as Measure 142, which registered low and slow uptake, mainly explained by the excessive high conditions. Despite this, 149 PGs were reported by the end of 2013 (MADR, 2020a).

In the 2014-2020 programming period, Romania implemented major development measures dedicated to smallholders, associations, and the short food supply sector: Sub-measure 9.1 "Establishment of producer groups and organizations in agriculture and forestry" or Sub-measure 16.4 "Support for horizontal and vertical cooperation among actors in the supply chain" (MADR, 2020a).

According to the ongoing evaluation report, 177 projects for associative forms got financing (MADR, 2020b). A strong motive for cooperation and PG membership is the chance they offer in solving widespread economic impediments that small farms in Romania are confronted with: lacking financial resources, attaining production increase, accessing bank loans, commercialising their produce (Möllers and Bîrhală, 2014). However, the achieved results in establishing PGs seem to be less than expected, the interim evaluation stating problems in attracting interested farmers (MADR, 2019).

Perceived economic benefits and social norms, referring to social pressure or support from the family are the most significant influences which determine the attitude of small farmers towards producer groups. The research of Möllers and peers (2018) showed also that subsidised offers are interesting for the economic and financial needs of smallholders. Thus, an efficient measure to improve the disposition to participate in PGs is to facilitate good information of the farmers about the economic benefits (Möllers et al., 2018), although creating more accessible conditions would help as well.

\subsection{Alternative food networks in Romania - challenges and opportunities}

Berti and Mulligan (2016) sum up the motives and the negative impacts of diminishing small-scale agriculture: "Farms' declining share of profit, the costprice squeeze of commodity production and the unequal bargaining power in the food chain has increased barriers to market access for small family farms, contributing, together with other structural changes, to the gradual de-agrarisation, land abandonment and depopulation of areas in which such holdings predominate" (Berti and Mulligan, 2016, p. 616).
In Romania, peasant agriculture is mainly regarded as a relic from the past (Smeds, 2015), and the national rural development policies of the last decades favoured large agri-business units and focused on ameliorating the competitiveness of the agricultural sector to participate in global markets, and to reduce the labour force employed in agriculture (MADR, 2019, 2020a).

The currently estimated 3 million small-scale agricultural units (under 5 hectares) are perceived in two contrasting ways: one prevailing stand considers these holdings a drawback and a major inconvenience for the Romanian agri-food sector, others adhere to the opinion that these smallholders are fundamental for the development of sustainable consumption strategies facilitated by SFSCs (Tanasă, Brumă and Doboş, 2015).

In most of the EU member states, the concept of short food supply chain stands for innovative measures to support local agriculture systems, maintaining the social fabric of rural areas and healthy food consumption. In Romania, informal SFSCs prior to 1989 were rather "crisis" solutions for the urban population whose access to food was consistently limited owing to deficient supply and foodstuff shortages.

Even though the legally registered cooperative sector in Romania is currently insignificant, awareness is raising that smallholder collaboration could be a viable remedy in terms of strengthening competitiveness and efficiency (Möllers et al., 2018), and SFSCs might facilitate and have a share in the survival and revival of small-scale farms and processing units (Tanasă, 2015, in Tanasă, Brumă and Doboş, 2015).

Besides the prevailing historical rural-urban link and the large number of small-scale agricultural holdings, there are also recent trends which demonstrate potential for the development of short food supply chains. Hereby we mean the growing demand for regional healthy food, the increasing number of local certified producers and the multitude of specialised retail shops (Tanasă, Brumă and Doboş, 2015). Several models of AFNs are emerging nationwide.

In this survey, we focus on "neotraditional" (Santini and Gomez y Paloma, 2013) SFSCs and we depict face-to-face (Table 1) and sales of proximity (Table 2) types of AFNs to illustrate their mechanism, costs and benefits for the involved stakeholders, chances and challenges of growth and their effectiveness to enhance the socio-economic status of the regions. The survey conducted by Smeds (2015) on Cutia Țăranului and ASAT schemes active in ClujNapoca, and the surveys of Möllers and Bîrhală (2014) on ASAT in Timişoara confirm the widespread consumer profile of AFNs, namely: most of the consumers are young, highly educated and economically well-situated families, and this raises the 
issue of inclusiveness and accessibility. The chance of an innovative alternative to disseminate and unfold in an effective manner depends on the ease with which it is adoptable by the mass, whereas accessibility can be regarded in various manners: (1) spatial distribution of AFNs, conveniently reachable by the people who want to be part of them, and (2) the price of the agri-food goods (Barbera and Dagnesa, 2016). As seen in these examples, SFSCs evolve mostly in urban centres and their proximity, due to the potential consumers originating in urban areas. A large-scale land use plan developed with the contribution of the authorities would facilitate the development of SFSCs and periurban agriculture. A regionally integrated production, distribution and consumption system could enable comprehensive development and improve the accessibility for both interested producers and consumers. Further on, the coordinator of the Bejön a vidék movement mentions the network of specialised farmers' retail shops as a tool to improve the market access of regional smallholder producers and the access of customers to regional products.

Table 1. Examples of face-to-face type SFSCs in Romania.

\begin{tabular}{|c|c|c|c|}
\hline \multirow[b]{2}{*}{$\begin{array}{l}\text { Sales of } \\
\text { proximity }\end{array}$} & \multicolumn{3}{|c|}{ Name of the initiative } \\
\hline & $\begin{array}{l}\text { ASAT (Asociația pentru Susținerea } \\
\text { Agriculturii Țărănești/Association for } \\
\text { the Support of Peasant Agriculture) }\end{array}$ & $\begin{array}{l}\text { Cutia Ţăranului } \\
\text { (The Peasant's Box) }\end{array}$ & $\begin{array}{l}\text { Bejön a vidék/Satul vine la } \\
\text { oraș (The Village Comes to } \\
\text { the City) }\end{array}$ \\
\hline Type & Community supported agriculture & $\begin{array}{l}\text { Direct sales off-farm to } \\
\text { private consumers }\end{array}$ & $\begin{array}{l}\text { Direct sales off-farm to private } \\
\text { consumers }\end{array}$ \\
\hline Description & $\begin{array}{l}\text { Network of associations of individual } \\
\text { consumers supporting one or more } \\
\text { local farms and/or food producers }\end{array}$ & $\begin{array}{l}\text { Producers deliver a box- } \\
\text { scheme }\end{array}$ & $\begin{array}{l}\text { Producers sell their products } \\
\text { at a monthly organised market } \\
\text { in Cluj-Napoca; they have also } \\
\text { a specialised retail shop }\end{array}$ \\
\hline $\begin{array}{l}\text { Relation type; } \\
\text { What is meant } \\
\text { by short? }\end{array}$ & $\begin{array}{l}\text { Consumer-producer partnerships; } \\
\text { contractual relation }\end{array}$ & Producer-to-consumer & $\begin{array}{l}\text { Producer-to-consumer; } \\
\text { Producer-specialised retail } \\
\text { shop-consumer }\end{array}$ \\
\hline Funding year & $\begin{array}{l}\text { Between } 2008 \text { and } 2011 \text { ASATs pilot } \\
\text { phase in Timişoara; } 2014 \text { - founding } \\
\text { of the association }\end{array}$ & 2011 & $\begin{array}{l}\text { 2016: market } \\
\text { 2019: retail shop }\end{array}$ \\
\hline $\begin{array}{l}\text { Number of } \\
\text { actors }\end{array}$ & 8 partnerships (2017) & $\begin{array}{l}22 \text { producers and } \\
\text { farmers }(2020)\end{array}$ & $\begin{array}{l}\text { At least } 70 \text { farmers and } \\
\text { producers (2019) }\end{array}$ \\
\hline $\begin{array}{l}\text { Type of } \\
\text { products }\end{array}$ & Mainly vegetables & \multicolumn{2}{|c|}{$\begin{array}{l}\text { Fresh and processed fruit and vegetables, meat products, } \\
\text { milk and dairy products, eggs, honey, beverages, bread } \\
\text { and pastry, pasta }\end{array}$} \\
\hline $\begin{array}{l}\text { Area and } \\
\text { territory }\end{array}$ & $\begin{array}{l}\text { București, Cluj-Napoca, Sibiu, } \\
\text { Odorheiu Secuiesc and Timișoara } \\
\text { (2017) }\end{array}$ & $\begin{array}{l}\text { Active networks in } 9 \\
\text { cities: Arad, Brașov, } \\
\text { București, Cluj-Napoca, } \\
\text { Iași, Ploiești, Sibiu, } \\
\text { Timișoara, Târgu Mureș }\end{array}$ & $\begin{array}{l}\text { Outlet area is Cluj-Napoca; } \\
\text { most of the farmers and } \\
\text { producers are members of the } \\
\text { association; Transylvanian } \\
\text { farmers and producers }\end{array}$ \\
\hline $\begin{array}{l}\text { Health and } \\
\text { food quality }\end{array}$ & \multicolumn{3}{|c|}{$\begin{array}{l}\text { Broad variety of local, seasonal, and good quality foods; mostly organic products, but without } \\
\text { certification }\end{array}$} \\
\hline $\begin{array}{l}\text { Sustainability } \\
\text { issues }\end{array}$ & \multicolumn{3}{|c|}{ Distribution in proximity; organic farming methods; traditional products } \\
\hline $\begin{array}{l}\text { Growth and } \\
\text { development, } \\
\text { chances, and } \\
\text { challenges }\end{array}$ & $\begin{array}{l}\text { Further growth might be possible; an } \\
\text { impediment is the meagre } \\
\text { entrepreneurial spirit of small-scale } \\
\text { farmers; contractual constraints might } \\
\text { be a deterrent both for producers and } \\
\text { consumers }\end{array}$ & $\begin{array}{l}\text { Limitations due to } \\
\text { small-scale } \\
\text { production; } \\
\text { recruitment of new } \\
\text { producers; existence } \\
\text { of demand }\end{array}$ & $\begin{array}{l}\text { Accessing further marketing } \\
\text { channels; increasing the pool } \\
\text { of producers }\end{array}$ \\
\hline $\begin{array}{l}\text { Innovative } \\
\text { elements }\end{array}$ & $\begin{array}{l}\text { Consumers know the identity of the } \\
\text { producer and establish relations of trus }\end{array}$ & $\begin{array}{l}\text { Online order; home } \\
\text { delivery }\end{array}$ & $\begin{array}{l}\text { Retail shop of a producer } \\
\text { association }\end{array}$ \\
\hline
\end{tabular}

Regarding the motivations of consumers to participate in AFNs, prevalent are self-centred reasons such as easy acquisition of tasty, fresh, and healthy food
(Smeds, 2015). Traditional farming that uses natural fertilizer is still widespread, and a large share of the production is close to organic standards (Möllers and 
Bîrhală, 2014), even if not certified. Small farmers frequently promote their products in the local market as "traditional" or "natural". Several farmers and processors of AFNs describe their products as certified "traditional product", meaning that the product is "produced within the national territory using only local raw materials, which do not contain food additives, it is based upon a traditional recipe, a traditional production and/or processing method and a traditional technological process, and it is distinguished from other similar products belonging to the same category" (MADR, 2013, p. 1).

The demand for healthy, fresh, local food and traditional products is increasing, where "regional" and "traditional" seems to be more important for the consumer than certified bio, the quality of the product complying with the local perceptions of "good taste" (Morgan et al., 2006, in Smeds, 2015).

This market demand leads some producers to false claims about the origin of their products. Hence, the AFNs could guarantee the quality attributes of the marketed products, as the schemes recruit producers according to certain criteria. In the Romanian example, social reasons, like being part of a community, contribution to the welfare of the farmer and an active endorsement of peasant agriculture (Smeds, 2015), as well as environmental reasons, are not necessarily the triggering force to purchase in AFNs but gain in significance after being a member of an alternative food network.

Table 2. Examples of proximity type sales of SFSCs in Romania.

\begin{tabular}{|c|c|c|}
\hline \multirow{2}{*}{$\begin{array}{l}\text { Sales of } \\
\text { proximity }\end{array}$} & \multicolumn{2}{|c|}{ Name of the initiative } \\
\hline & $\begin{array}{l}\text { RAF (Romanian-American Foundation) pilot } \\
\text { project on food hubs }\end{array}$ & Székely termék (Sekler Product) \\
\hline Type & Food hub & Agricultural Cooperative; trademark \\
\hline Description & $\begin{array}{l}\text { Food hubs initiated and coordinated by NGOs; } \\
\text { intermediary organisations offer a large variety of } \\
\text { products from various local/regional producers and } \\
\text { processors, and deliver a box-scheme }\end{array}$ & $\begin{array}{l}\text { Initiated by the Harghita County Council and } \\
\text { the Chamber of Commerce with the aim to } \\
\text { support the local small farmers and artisans, } \\
\text { and to represent their interests }\end{array}$ \\
\hline $\begin{array}{l}\text { Relation type. } \\
\text { What is meant } \\
\text { by short? }\end{array}$ & $\begin{array}{l}\text { Producer - food hub intermediary (online shop) - } \\
\text { consumer }\end{array}$ & $\begin{array}{l}\text { Producer - retail shops - consumer; } \\
\text { Producer - consumer; } \\
\text { Producer - online shop - home delivery to } \\
\text { consumer }\end{array}$ \\
\hline Funding year & 2017 & 2013 \\
\hline $\begin{array}{l}\text { Number of } \\
\text { actors }\end{array}$ & $\begin{array}{l}5 \text { NGOs, } 5 \text { food hubs, around } 200 \text { farmers and } \\
\text { processors (2020) }\end{array}$ & 46 producers (2014) \\
\hline $\begin{array}{l}\text { Type of } \\
\text { products }\end{array}$ & $\begin{array}{l}\text { Fresh, seasonal, and processed fruit and vegetables, } \\
\text { meat, milk and dairy products, eggs, honey, } \\
\text { beverages, bread, and pastry products }\end{array}$ & $\begin{array}{l}464 \text { certified (2014) food products (bread and } \\
\text { pastry, honey, processed fruit and vegetables, } \\
\text { beverages, meat products); handcraft } \\
\text { artifacts (pottery, objects made of cornhusk); } \\
\text { industrial products (pottery, mineral water, } \\
\text { dairy products, onion, wooden toys, } \\
\text { traditional style clothes) }\end{array}$ \\
\hline $\begin{array}{l}\text { Area and } \\
\text { territory }\end{array}$ & $\begin{array}{l}5 \text { regions; } 3 \text { urban centres (Cluj-Napoca, Iași, } \\
\text { Odorheiu Secuiesc) and their urban fringes }\end{array}$ & $\begin{array}{l}\text { Producers and main outlet markets: } \\
\text { Harghita, Covasna and Mureș counties }\end{array}$ \\
\hline $\begin{array}{l}\text { Health and } \\
\text { food quality }\end{array}$ & \multicolumn{2}{|c|}{$\begin{array}{l}\text { Broad variety of local, seasonal, and quality goods; mostly organic products, traditional recipes and } \\
\text { products, some certified producers }\end{array}$} \\
\hline $\begin{array}{l}\text { Sustainability } \\
\text { issues }\end{array}$ & $\begin{array}{l}\text { Scaling-up and scaling-out process without } \\
\text { endangering the defining proximity aspect between } \\
\text { the location of production and consumption }\end{array}$ & $\begin{array}{l}\text { Quality certified by the trademark; } \\
\text { community building function }\end{array}$ \\
\hline $\begin{array}{l}\text { Growth and } \\
\text { development, } \\
\text { chances, and } \\
\text { challenges }\end{array}$ & $\begin{array}{l}\text { recruiting certified and reliable producers and } \\
\text { identifying and maintaining loyal, long-term } \\
\text { customers; logistics; human resources; economic } \\
\text { viability of the endeavour }\end{array}$ & $\begin{array}{l}\text { Possibility to certify further products; expand } \\
\text { the market (national and international) }\end{array}$ \\
\hline $\begin{array}{l}\text { Innovative } \\
\text { elements }\end{array}$ & One intermediary; coordinated by NGOs & $\begin{array}{l}\text { Initiatives of a municipality administration; } \\
\text { non-food products included; initiative of an } \\
\text { ethnic community }\end{array}$ \\
\hline
\end{tabular}

The consumers have numerous benefits granted, but they also have to adjust to the AFNs, as 22 consumers might be confronted with a change of their cooking routines, shopping might require more 
organizational efforts, product variety and differentiation is low (seasonality) and shortages of harvest could happen owing to climate or pest adverse events, constraints in natural resources availability and allocation (Carbone, Gaito and Senni, 2007; Möllers and Bîrhală, 2014).

The CSA-type ASAT is the most exigent and ambitious in terms of overall sustainability, through the focus on community and solidarity, yet other schemes might be more attractive due to their relative flexibility. Analysing the evolution of the ASAT partnerships, one can notice a decrease of their number. After the pilot project conducted during 2008-2012 in Timişoara, with one producer, from 2012 on, ASAT expanded to different regions. In 2013, the number of $A S A T$ partnerships grew to 13 main ASATs (with weekly vegetable baskets), and more than 20 ASATs of other foods (milk and cheese, honey, eggs, meat, bread and cakes, jams, fresh fruit grown in traditional orchards, and forest fruit, etc.) which were present in Arad, Bucharest, Cluj-Napoca, Odorheiu Secuiesc, Oradea and Timișoara (Hașdeu, 2014). According to the ASATwebsite, in 2017, there were 8 active ASAT-partnerships in București, Cluj-Napoca, Sibiu, Odorheiu Secuiesc and Timişoara (ASAT - Asociația pentru Susținerea Agriculturii Țărănești, asatromania.ro).

The producers take part in AFNs since it is a more secure and rewarding market, they might carry on a heritage, and several producers voice a sense of pride in being a peasant, knowing that their work is valuable and appreciated (Smeds, 2015). On the other hand, according to our observations, among the smallholders for processed food products we often encounter young innovative entrepreneurs, who are in search for a market for their high value products. Advantage for farmers is their control over price and production (Mastronardi et al., 2015; Sage, 2003b), and certain types of AFNs, in which consumers commit to longterm, diminish economic uncertainties caused by alterations in production and sales volume (Galli and Brunori, 2013).

Even though producers participating in AFNs gain entrepreneurial skills (Mastronardi et al., 2015), these demand significant additional effort (Carbone, Gaito and Senni, 2007) and the requirement for higher amount of work and additional investments can cause difficulties or create barriers to economic success particularly for small scale producers (Santini and Gomez y Paloma, 2013; Galli and Brunori, 2013; Barberaa and Dagnesa, 2016). Therefore, the guidance of a selfless third party with experience during the first phase of group formation and establishment of the network could help to overcome the difficulties (Möllers et al., 2018). The coordinator of the Bejön a vidék movement confirms the fact that farmers and producers rarely establish a cooperation or initiate a specialised shop by themselves. The intervention of professionals would be advisable, as it is them who initiate farmers' markets and specialised retailers as well. Farmers are preoccupied by the production, so external support for the marketing is welcome. In this sense is the action of the Romanian-American Foundation (RAF) which supported 5 NGOs in creating and conducting 5 food hubs, which offer a favourable alternative for the distribution and sale of goods produced by regional small-scale farmers and processors (https://www.rafonline.org/programe/dez voltareafood-hub-urilor/?cn-reloaded=1).

Also ASAT was initiated by CRIES-Association with the aim to increase opportunities for small food producers to sell their products at a fair price, which ensures for the farmer a decent living. Among the numerous SFSCs created by private persons or NGOs, the Székely Termék (Sekler Product) Agricultural Cooperative stands out as being initiated by the Harghita County Council and the Chamber of Commerce (http://szekelytermek.ro).

Some of the AFNs hosting organisations have a large part in educating producers and consumers in the direction of sustainable production and consumption by information dissemination and awareness campaigns on the importance of healthy local food, and of supporting sustainable agriculture and biodiversity conservation not only among the own stakeholders, but also in the media. ASAT and food hubs offer for the producers consulting and training on various topics (e.g. communication skills, financial planning, natural farming practices), and the Bejön a vidék supported smallholders in the authorisation process.

The coordinator of the Bejön a vidék movement mentions an increase of people who consciously search for food products manufactured by local and regional producers. He thinks that this trend could induce a change in the mindset of the farmers and motivate them to process their primary agricultural products, at least partially. The authorisation and certification process might be a financial and bureaucratic burden, however the increasing demand for smallholders' products, the chance to benefit from different emerging marketing channels, as well as a likely fast return of investment, could motivate the small-scale producers to undergo the needed procedures and procure the required gear. Community fruit and vegetables processing plants, accessible for smallholders, could be a solution as well. Some of the producers who market their products in the frame of Székely Termék use this kind of facilities.

Given the supplementary costs of being smaller than agri-food enterprises, public and private funding should address improving human capital, skilltraining programs, organizational assistance, and infrastructure enabling collaborations and localized economies of scale (Demartini, Gaviglio and Pirani, 2017). As observed in the case of the food hubs or in the 
specialised retail shops in Cluj-Napoca, producers tend to market their products through diverse channels, so to mitigate market volatility.

Several studies argue that farms participating in AFNs schemes tend to implement sustainable, less intensive production methods with lower environmental impact, which improve biodiversity and have a positive impact on the landscape (Galli and Brunori, 2013; Mastronardia et al., 2015; Demartini, Gaviglio and Pirani, 2017; Wellner, 2018). Consumers' demand for variety has triggered farmers to offer a wide range of different goods (Mastronardi et al., 2015), to cultivate diverse varieties, even autochthonous breeds and traditional fruit and vegetables (Demartini, Gaviglio and Pirani, 2017; Galli and Brunori, 2013). A further advantage in environmental sustainability derives from the short length of time between harvest and sale, reducing the energy used for storage, less processing and packaging to save energy and resources as well (Galli and Brunori, 2013; Wellner, 2018).

Environmental benefits can also favour broader territories and communities: supporting multifunctional farming could counteract urban sprawl, devaluation, and abandonment of agricultural land at the urban fringe, but also offer new prospects for agriculture in marginalised rural areas (Galli and Brunori, 2013).

\section{CONCLUSIONS}

For Romania, we can conclude that the AFNs provide a product market for food producers, reduce the time of product selling, ensure that the producer receives a fair price and allow a secure and steady income, support local small-scale agriculture, and promote environmentally friendly practices, local biodiversity, and healthy products, support the development of employment in the agriculture and food production sector. The participating consumers might improve their gastronomic habits, incorporating more seasonal and local ingredients, with high-quality nutritional impact, and in long-term, they could become increasingly aware of the role of responsible consumption to support the local economy and smallholders. They also foster a sustainable food paradigm by accentuating socio-cultural aspects of agrifood which confer AFNs distinctive qualitative values from CFNs (Smeds, 2015). In Romania, this manifests through farmers and processors experiencing pride about supplying urban citizens with food, and consumers regarding peasants as a significant element of the Romanian identity (Banini and Ilovan, 2021).

Thus, keeping in mind their potential socioecological and economic gains, it is relevant to investigate how to enable the evolvement of AFNs. Current policy in the European Union considers food and farming as a tool for broad regional development, environmental, and public health objectives (Whatmore, Stassart and Renting, 2003). In the conception of multifunctional agriculture, farming is understood not only as a process of material production, but also care about rural landscapes, preserving biodiversity, contributing to employment and to the viability of rural areas (Smutna, 2018). There were arguments that the above-mentioned positive externalities and ecological services are produced more by those who farm on smaller areas, less intensive and focusing on diversification. In the frame of the Commune Agricultural Polities (CAP) reforms embracing a multi-sectorial, regionally focused, and more endogenous concept of integrated rural development, AFNs are an innovative expression of the "new" model of rural development (Goodman and Goodman, 2009). However, both on European as well as on Romanian level, the AFNs perceived as innovation are still marginal to the food market and are very dependent on the political framework and organization, and it is the issue of how they will be capable to integrate. Changing agricultural policies, market opportunities or constraints, and changing consumer behaviour are major external conditions which limit or favour the growth of SFSCs (Galli and Brunori, 2013). SFSCs are coping as well with general challenges of rural and agricultural development: such as outmigration that reduces the available endogenous supply of labour or the increasing pressure on land due to urbanization (Galli and Brunori, 2013).

Most of the AFNs depicted in the survey have occurred without significant institutional support, but institutional assistance and associational development might sustain the initiatives over time (Marsden, Banks and Bristow, 2000). In some cases, especially in the case of "neotraditional" AFNs, external third parties (e.g. NGOs) can play a major role in setting up and supporting them, as seen also in the Romanian case studies. It is necessary that participants will be proactive and policy makers should either support them, or at least not impede such endeavours (Galli and Brunori, 2013; Aggestam, Fleiß and Posch, 2017).

Numerous institutional tools are currently being applied in the EU to support SFSCs (Santini and Gomez y Paloma, 2013; Galli and Brunori, 2013), but not all of them can be identified or are being assimilated by the regulatory system in Romania. The financial mechanisms hosted by the CAP or the European Fund for Rural Development aiming to promote the sustainable development of rural areas experience a poor reception. Similar is the situation in other policy areas regarding the reform of legal framework for cooperatives and other associative models decisive for short supply chains (MADR, 2020b), communication and promotion instruments designated to disseminate knowledge and understanding about food quality and quality products. 


\section{Alternative Food Networks in Romania - Effective Instrument for Rural Development? Journal of Settlements and Spatial Planning, Special Issue, no. 8 (2021) 15-27 Territorial Identities and Sustainable Development. Challenges and Solutions}

As reported above, producer groups and other forms of association are significant for the commercialisation of small producers. Smallholders are inclined to participate in producer groups and benefit from the grants facilitated by the EU. However, for the sustainability of PGs, policy makers should ensure that they are not misused as a short-term tool to ingress subsidies (Möllers et al., 2018).

Flexible regulations and adjustments to the context of small-scale production, existent in the EU, are currently not implemented in Romania. Quality policy and labelling measures, in particular organic regulations and territorial and quality branding, are well-functioning mechanisms, but to a lesser extent in Romania, mainly because of costs and bureaucracy. Local facilities (e.g. storage, processing) are punctually present, generally owing to the efforts of NGOs and civil society, and to a lesser extent from public investments.

Even though direct marketing is at present not suitable for all the farms and small-scale producers, we can affirm that there are plenty thriving examples of short food supply chains, encouraging options for numerous farms and artisanal producers, notably in peri-urban areas. For the time being it is yet too early to make statements regarding the effectiveness of the alternative food networks in the process of overall rural development, however it shows a promising evolution. The increasing demand for qualitative regional products is a strong fundament and motivating factor for producers to maintain and extend their activity. Yet it is clear, that the support of the public policy is essential for the AFNs to overcome their status as niche phenomenon, increase their market share, and to evolve into an effective medium to enhance the socioeconomic status of the regions and foster progress of rural areas.

\section{ACKNOWLEDGEMENTS}

The research idea was developed during a short-term research stay at the "IAMO, Leibniz Institute of Agricultural Development in Transition Economies", Halle in August-September 2019 as part of a Leibniz ScienceCampus "Eastern Europe - Global Area" (EEGA) grant.

\section{REFERENCES}

Aggestam V., Fleiß E., Posch A. (2017), Scaling-up short food supply chains? A survey study on the drivers behind the intention of food producers. Journal of Rural Studies, 51, pp. 64-72. DOI: 10.1016/j.jrurstud.2017.02.003

Ancuţa C., Ianăş A., Muţulescu C. (2013), Selected aspects of the effects of the transition process upon the Romanian rural space and system. In: Cawley M., Bicalho A. M. de S. M. and Laurens L. (eds.), The
Sustainability of Rural Systems: Global and Local Challenges and Opportunities, Galway and Okayama, Whitaker Institute \& CSRS of the International Geographical Union, pp. 175-189. URL: http://hdl.handle.net/10379/6064. Accessed on 13.01.2021.

ASAT - Asociația pentru Susținerea Agriculturii Țărănești [Association for the Support of Peasant Agriculture]. URL: asatromania.ro. Accessed on 13.012021.

Banini T., Ilovan O.-R. (2021), Introduction: dealing with territorial/place identity representations. In: Banini T., Ilovan O.-R. (eds.), Representing Place and Territorial Identities in Europe. GeoJournal Library, vol. 127. Springer, Cham, pp. 1-19. DOI: https://doi.org/10.1007/978-3-030-66766-5_1

Barbera F., Dagnesa J. (2016), Building alternatives from the bottom-up: the case of alternative food networks. Agriculture and Agricultural Science Procedia, 8, pp. 324-331. DOI: https://doi.org/10.1016/j.aaspro. 2016.02.027

Bejön a vidék - Sat în oraş - Élelmiszerüzlet itt: ClujNapoca [The Village Comes to the City]. URL: https://bejon-a-videk-sat-in-oras.business.site/. Accessed on 13.01.2021.

Berti G., Mulligan C. (2016), Competitiveness of small farms and innovative food supply chains: the role of food hubs in creating sustainable regional and local food systems. Sustainability, 8, pp. 616-647. https://doi.org/10.3390/su8070616

Bilewicz A., Śpiewak R. (2015), Enclaves of activism and taste: Consumer cooperatives in Poland as alternative food networks. Socio.hu, pp. 145-166. DOI: 10.18030/socio.hu.2015en.145

Bîrhală B. A.-M., Möllers J. (2014), Community supported agriculture in Romania. Is it driven by economy or solidarity? IAMO Discussion Paper No. 144. ISSN: $1438-2172$

Carbone A., Gaito M., Senni S. (2007), Consumers' buying groups in the short food chains: alternatives for trust. International European Forum on Innovation and System Dynamics in Food Networks Officially endorsed by the European Association of Agricultural Economists (EAAE), Innsbruck-Igls, Austria, February 15-17, 2007. DOI: 10.22004/ag.econ.6594

Chiffoleau Y., Millet-Amrani S., Canard, A. (2016), From short food supply chains to sustainable agriculture in urban food systems: food democracy as a vector of transition. Agriculture 6(4), pp. 57-75. https://doi.org/10.3390/agriculture6040057

Cutia Ţăranului - Taranii romani livreaza hrana proaspata, crescuta local, direct la usa dvoastra [The Peasant's Box]. URL: cutiataranului.ro. Accessed on 13.01.2021.

Dansero E., Puttilli M. (2014), Multiple territorialities of alternative food networks: six cases from Piedmont, Italy. Local Environment. The 
International Journal of Justice and Sustainability, 19(6), pp. 626-643. DOI: https://doi.org/10.1080/13549839.2013.836163

De Olde E. M., Valentinov V. (2019), The moral complexity of agriculture: a challenge for corporate social responsibility. Journal of Agricultural and Environmental Ethics, 32, pp. 413-430. DOI: 10.1007/s10806-019-09782-3

Demartini E., Gaviglio A., Pirani A. (2017), Farmers' motivation and perceived effects of participating in short food supply chains: evidence from a North Italian survey Agric. Econ. - Czech, 63(5), pp. 204-216. DOI: 10.17221/323/2015-AGRICECON

Galli F., Brunori G. (eds.) (2013), Short Food Supply Chains as Drivers of Sustainable Development. Evidence Document. Documents developed in the framework of the $\mathrm{FP}_{7}$ project FOODLINKS (GA No. 265287). Laboratorio di studi rurali Sismondi. ISBN: 978-88-90896-01-9

Goodman D., Goodman M. (2009), Alternative food networks. In: Kitchin R., Thrift N. (eds.), International Encyclopaedia of Human Geography, Elsevier, pp. 208220. ISBN: 9780080449104

Harris E. M. (2010), Eat local? Constructions of place in alternative food politics. Geography Compass, 4(4), pp. 355-369. DOI: https://doi.org/10.1111/j.17498198.2009.00298.x

Haşdeu B. P. (2014), Best practices from the GRUNDTVIG "Local Heritage in the Mirror of Europe" Project, partner countries. URL: [PDF] Best practices from the GRUNDTVIG "Local heritages in the mirror of Europe” project partner's countries | Semantic Scholar. Accessed on 15.02. 2021.

Havadi-Nagy K. X. (2021), Assessment of alternative food networks in Romania. The pilot project of Food hubs: Is this model relevant for Romania? Mitteilungen der Österreichischen Geographischen Gesellschaft (accepted for publication).

Ilbery B., Maye D. (2005), Alternative (shorter) food supply chains and specialist livestock products in the Scottish-English borders. Environment and Planning A: Economy and Space, 37(5), pp. 823-844. DOI: https://doi.org/10.1068/a3717

Ilovan O.-R., Jordan P., Havadi-Nagy K. X., Zametter T. (2016), Identity matters for development. Austrian and Romanian experiences. Transylvanian Review, XXV(Supplement 1), pp. 261-276.

Jarosz L. (2008), The city in the country: growing alternative food networks in metropolitan areas. Journal of Rural Studies, 24(3), pp. 231-244. DOI: 10.1016/J.JRURSTUD.2007.10.002

Jones O., Kirwan J., Morris C., Buller H., Dunn R., Hopkins A., Whittington F., Wood J. (2010), On the alternativeness of alternative food networks: sustainability and the co-production of social and ecological wealth. In: Fuller D., Jones A. E. G., Lee R. (eds.), Alternative Spaces of Economy, Society and 26
Politics: Interrogating Alterity. Oxford: Ashgate, pp. 95109 (Chapter 6). ISBN: 978-0-7546-7341-5

Kirwan J., Maye D., Brunori G. (2017), Acknowledging complexity in food supply chains when assessing their performance and sustainability. Journal of Rural Studies, 52, pp. 21-32. https://doi.org/10.1016/j.jrurstud.2017.03.008

Kovács Cs. M. (2003), The market potential and patterns of contemporary agriculture in Romania's northwestern plain. In: Abele S., Frohberg K. (eds.), Subsistence agriculture in Central and Eastern Europe: how to break the vicious circle? Studies on the agricultural and food sector in Central and Eastern Europe, 22, Leibniz Institut für Agrarentwicklung in Mittel- und Osteuropa (IAMO), Halle (Saale), pp. 124132. ISBN: 3-9809270-2-4

Marsden T., Banks J., Bristow G. (2000), Food supply chain approaches: exploring their role in rural development. Sociologia Ruralis, 40(4), pp. 424-438. DOI: https://doi.org/10.1111/1467-9523.00158

Mastronardi L., Marino D., Cavallo A., Giannelli A. (2015), Exploring the role of farmers in short food supply chains: The case of Italy. International Food and Agribusiness Management Review, 18(2), pp. 109-130. DOI: 10.22004/ag.econ.204139

Ministerul Agriculturii şi Dezvoltării Rurale (MADR) (2013), Ordin privind atestarea produselor tradiționale [Certification of traditional products]. 0688 BT-p1-color: Macheta P1 pepi.qxd (madr.ro). Accessed on 15.02. 2021.

Ministerul Agriculturii şi Dezvoltării Rurale (MADR) (2019), Evaluarea on-going a PNDR 20152020 in perioada 2017-2020, Studiul de evaluare II RAI 2019, Rapoarte de evaluare - Ministerul Agriculturii şi Dezvoltării Rurale (madr.ro) [The on-going evaluation of the NRDP 2015-2020 during 2017-2020, Evaluation study II - RAI 2019]. URL: studiu-de-evaluareII_RAI_RO.pdf (madr.ro). Accessed 22.01.2021.

Ministerul Agriculturii şi Dezvoltării Rurale (MADR) (2020a), Programul Național de Dezvoltare Rurală pentru perioada 2014-2020. [National Programme for Rural Development for the period 20142020]. URL: PNDR-2014-2020-versiunea-XI-aprobata19.10.2020.pdf (madr.ro). Accessed 22.01.2021.

Ministerul Agriculturii şi Dezvoltării Rurale (MADR) (2020b), The on - going evaluation of NRDP 2014 - 2020 during 2017 - 2020. Evaluation study V Small farm and the development of associate forms, Executive summary. URL: https://www.madr.ro/docs/dezvoltarerurala/evaluare_/2020/rezumat-executiv-studiu-deevaluare-V_EN.pdf. Accessed 22.01.2021.

Möllers J., Bîrhală B. A.-M. (2014), Community supported agriculture: a promising pathway for small family farms in Eastern Europe? A case study from Romania. Landbauforschung Applied Agricultural and 


\section{Alternative Food Networks in Romania - Effective Instrument for Rural Development? Journal of Settlements and Spatial Planning, Special Issue, no. 8 (2021) 15-27 Territorial Identities and Sustainable Development. Challenges and Solutions}

Forestry Research, 3/4(64), pp. 139-150. DOI: 10.3220/LBF_2014_139-150

Möllers J., Traikova D., Bîrhală B. A. M., Wolz A. (2018), Why (not) cooperate? A cognitive model of farmers' intention to join producer groups in Romania. Post-Communist Economies, 30(1), pp. 56-77. DOI: 10.1080/14631377.2017.1361697

Mundler P., Laughrea S. (2016), The contributions of short food supply chains to territorial development: A study of three Quebec territories. Journal of Rural Studies, $\quad 45, \quad$ pp. 218-229. https://doi.org/10.1016/j.jrurstud.2016.04.001

Petropoulou E. (2016), The role of short food supply chains in Greece - What opportunities for sustainable, just and democratic food systems at times of crisis? Sociology and Anthropology, 4, pp. 337-346. DOI: 10.13189/sa.2016.040506

Renting H., Marsden T., Banks J. (2003), Understanding alternative food networks: exploring the role of short food supply chains in rural development. Environment and Planning, 35, pp. 393-411. DOI: $10.1068 / \mathrm{a} 3510$

Robinson G. M. (2013), Agricultural sustainability: local challenges in a global context. In: Cawley M., Bicalho A.M. de S. M., Laurens L. (eds.), The Sustainability of Rural Systems: Global and Local Challenges and Opportunities, Galway and Okayama, Whitaker Institute \& CSRS of the International Geographical Union, pp. 15-26. ISBN: 978-0-9574255-O Roep D., Wiskerke H. (eds.) (2006), Nourishing networks: fourteen lessons about creating sustainable food supply chains, Wageningen University. ISBN: 905439157X

Romanian-American Foundation [RAF]. URL: https://www.rafonline.org/programe/dezvoltareafood-hub-urilor/?cn-reloaded=1. Accessed on 13.01. 2021.

Sage C. (2003a), Social embeddedness and relations of regard: alternative 'good food' networks in south-west Ireland. Journal of Rural Studies, 19, pp. 47-6o. DOI: https://doi.org/10.1016/So743-0167(02)oo044-X

Sage C. (2003b), Quality in alternative food networks: conventions, regulations and governance. Policies, governance and innovation for rural areas. International Seminar 21-23 November 2003, Università della Calabria, Arcavacata di Rende. SagePaperNovo31.doc (psu.edu).

Salasan C., Fritzsch J. (2009), The role of agriculture in rural poverty in Romania. Discussion Paper, No. 121, Leibniz Institute of Agricultural Development in Central and Eastern Europe, Halle (Saale). ISSN: 1438-2172

Santini F., Gomez y Paloma S. (eds.) (2013), Short food supply chains and local food systems in the EU. A state of play of their socio-economic characteristics. JRC Scientific and Policy Reports, European
Commission Joint Research Centre Institute for Prospective Technological Studies. DOI: 10.2791/88784 Schmutz U., Kneafsey M., Sarrouy Kay C., Doernberg A., Zasada I. (2018), Sustainability impact assessments of different urban short food supply chains: examples from London, UK. Renewable Agriculture and Food Systems, 33(6), pp. 518-529. DOI: https://doi.org/10.1017/S1742170517000564

Seyfang G. (2006), Ecological citizenship and sustainable consumption: examining local organic food networks. Journal of Rural Studies, 22, pp. 383-395. DOI: https://doi.org/10.1016/j.jrurstud.2006.01.003

Smeds J. (2015), Growing through connections-a multi-case study of two alternative food networks in Cluj-Napoca, Romania. Future of Food: Journal of Food, Agriculture and Society, 2(2), pp. 48-61. URL: https://www.thefutureoffoodjournal.com/index.php/F OFJ/article/view/132 Accessed 1.12.2020

Smutna Z. (2018), Alternative Food Networks in Münsterland. DBU Abschlußbericht.

Szekely termek [Sekler Porduct]. http://szekelytermek.ro/?SID=b6m9oh4rpjsktoo56tah lrojun. Accessed on 13.01.2021.

Tanasă L. (2014), Benefits of short food supply chains for the development of rural tourism in Romania as emergent country during crisis. Agricultural Economics and Rural Development, New Series, XI(2), pp. 181-193. Tanasă L., Brumă I.-S., Doboş S. (2015), The role of short food supply chains in the development of smallscale local producers. Case study: Harghita County. In: Agrarian Economy and Rural Development - Realities and Perspectives for Romania. $6^{\text {th }}$ Edition of the International Symposium, The Research Institute for Agricultural Economy and Rural Development (ICEADR), Bucharest, pp. 286-293. ISSN: 2285-6803

Watts C. H., Ilbery B., Maye D. (2005), Making reconnections in agro-food geography: alternative systems of food provision. Progress in Human Geography 29(1), pp. 22-40. DOI: 10.1191/o309132505ph526oa

Wellner M. (2018), Landwirtschaft und Gesellschaft: community supported agriculture als innovative Nische, Dissertation, Georg-August Universität Göttingen. http://hdl.handle.net/11858/oo-1735-0ooo-oo2E-

E4C7-3. Accessed 15.12.2020.

Whatmore S., Stassart P., Renting H. (2003), What's alternative about alternative food networks? Environment and Planning, 35, pp. 389-391. DOI: $10.1068 / \mathrm{a} 3621$

Wubben E. F. M., Fondse M., Pascucci S. (2013), The importance of stakeholder initiatives for business models in short food supply chains: the case of the Netherlands. Journal of Chain and Network Science, 13(2), pp. 139-149. DOI: https://doi.org/10.3920/JCNS2013.1004 